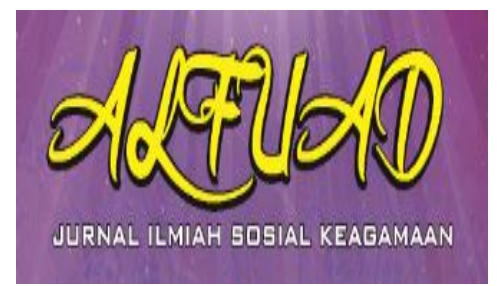

ALFUAD JOURNAL, 5 (2), 2021,(96-111)

(E-ISSN 2714-7606 P-ISSN 2614-4786 )

Available online at

http://ecampus.iainbatusangkar.ac.id/ojs/index.php/alfuad

\title{
The Effectiveness of Islamic Premarriage Counseling to Readiness for Household Life
}

\section{Irman*)}

Institut Agama Islam Negeri Batusangkar, Indonesia

E-mail: irman@iainbatusangkar.ac.id

\section{Silvianetri}

Institut Agama Islam Negeri Batusangkar, Indonesia

E-mail: silvianetri@iainbatusangkar.ac.id

\section{Zubaidah}

Institut Agama Islam Negeri Batusangkar, Indonesia

E-mail: zhubaidah09@gmail.com

\section{Putri Yeni}

Institut Agama Islam Negeri Batusangkar, Indonesia

E-mail: putriy3ni@gmail.com

\section{Wahyu Gusria}

Institut Agama Islam Negeri Batusangkar, Indonesia

E-mail: wahyugusria5@gmail.com

\section{Hanifah Usman}

Institut Agama Islam Negeri Batusangkar, Indonesia

E-mail: hanifahusman649@gmail.com

\section{Risvan Siraj}

Institut Agama Islam Negeri Batusangkar, Indonesia

E-mail: sirajrisva@gmail.com

*) Corresponding Author

Keywords: Counseling, Premarital, Readiness, Islam

\section{INTRODUCTION}

women to build a family in order to find peace and happiness. The Qur'an explains, among the signs of Allah's power is that $\mathrm{He}$ created for you wives of your

\begin{abstract}
The dominant problem experienced by prospective brides who will marry is the low level of readiness to enter married life, if neglected, this condition will have an impact on satisfaction after marriage. This study aims to examine the effectiveness of Islamic premarital counseling on increasing married life readiness. The research method used is experimental, especially the one group pretest and posttest design. The research population is prospective brides who have been registered at the Tanah Datar Regency Religious Affairs Office. The research sample was 8 people with the criteria indicated that the level of readiness for married life was low. Data were collected using a household readiness scale, with data analysis using the paired samples $t$ test through the SPSS computer program. release 20 . The results of the study found that Islamic premarital counseling is effective in increasing the readiness of married life of the prospective bride and groom. The increase occurred in every dimension of readiness for married life, namely mental, spiritual, social and financial readiness.
\end{abstract}


Rum, 21). This verse reveals the purpose of marriage, which is to reach the family of sakinah mawaddah warohmah.

Sakinah means a marriage that is built with the development of a natural and internal bond between husband and wife in a happy family life according to Islamic law (Djam'an, 1993). Sakinah family is characterized by straightforward intentions and strong relationship with God, love, mutual openness, courtesy, good communication, deliberation, tolerance, forgiveness, fairness, patience and gratitude (Chadijah, 2018). If linked to the Marriage Law No. 1 of 1974 Article 1 paragraph 3, explains that the sakinah family is a family based on a legal marriage, able to fulfill spiritual and material desires in a harmonious and balanced manner, covered with an atmosphere of affection between the family and its environment, able to understand, practice and deepen the values of faith, piety and akhlaqul karimah.

The realization of a sakinah family in the family requires a joint process through a strong inner bond between husband and wife. Shihab (2006) states that the sakinah family does not just come, but must be fought for. The struggle in reaching a sakinah family according to Kennedi (2005) is largely determined by how prepared the couple is before entering family life. Very good family life readiness is characterized by mental, financial, social and spiritual readiness (Krivickas et al., 2010; Idayu, 2018; Rahmah, 2018). The four dimensions of readiness for married life are the determinants in realizing a sakinah family.

Mental readiness for married life is related to the couple's emotional maturity towards marriage, the ability to mature themselves, the ability to respect each other, the ability to adjust to a partner, the ability to take responsibility, and emotional control (Idayu, 2018). As for financial readiness, Rahmah (2018) revealed that according to Islamic law, marriages that are not favored are because the couple who will marry do not have the economic ability. Willis (2008) revealed that economic factors are important because of the many needs that must be met in building a household. This means that economic readiness is an important part of entering married life.

Furthermore, social readiness begins with success in choosing a partner and views on marriage (Zulkifli, 1987). As for Conger (1994) explains that young people who experience confusion about their identity, find it difficult to productively form a family. Hurlock (1980) revealed that the problems that are often experienced by early adults are marriage without parental consent and adjustment in the family. This indicates the 
importance of social readiness in entering married life.

The religious readiness is understanding and awareness of religion. Willis (2008) revealed that the most important aspect for fostering a family is the cultivation of religious values, because religion teaches responsibility, courtesy, compassion and humanity. Rais (2014) that the solution for anticipating divorce requires knowledge of married life and the cultivation of sufficient religious values. Expert opinion about the importance of understanding religious values in building a household, it can be stated that in religion it is not enough just to understand, but there is religious awareness and its practice in everyday life.

The various opinions above indicate the need for readiness for the bride and groom when they enter married life. The debriefing of the prospective bride and groom is intended to provide provisions for married life related to the concept of the sakinah family. The provision of prospective brides is one of the important and strategic efforts to anticipate the occurrence of problems and efforts to solve problems in married life.

The debriefing for the bride and groom that has been carried out by the religious affairs office (KUA) in Indonesia, has not been able to reduce the number of divorces that occur, this is indicated by the high rate from year to year. Based on 2015 data in Indonesia, there were $5.89 \%$ divorced married couples with a total of about 3.9 million out of a total of 67.2 million households, in 2020, the percentage of divorces rose to $6.4 \%$ from 72.9 million households. or about 4.7 million couples (Lokadata, 2021). Especially in West Sumatra, the district with a high divorce rate is Tanah Datar Regency. The head of the Tanah Datar District Religious Court conveyed that divorce cases in Tanah Datar were relatively high, in 2020 there were 835 divorces (Singgalang Daily, July 16, 2021).

Scientifically, there are many methods of psychological services that can be provided to prospective brides, one of which is through premarital counseling. Giblin et al., (1985) stated that marriage enrichment through counseling is quite effective for couples who are about to get married. Premarital counseling is very important given to prospective brides, because they do not receive formal training to enter family life (Hoopes \& Fisher, 1984), and the establishment of domestic life is very dependent on initial debriefing before the bride and groom get married (Latipun, 2010). This is fundamental to the importance of premarital counseling because it is effective in preventing marital dysfunction (Sullivan et al., 2004), and can 
result in satisfying lifelong marriages (Wright \& Wright, 1992), and couples who receive premarital counseling have lower divorce rates and higher marital satisfaction (Scott, 2012; Carroll \& Doherty, 2003; Nelson \& Kelley, 2001).

Some of the opinions above indicate the importance of premarital counseling for prospective brides. Premarital counseling is a process of assistance provided for marriage preparation by supplying information about marriage, understanding the role in marriage, developing problem solving skills, emotional control and healthy relationships to prevent problems in marriage (Alpaslan, 1997; Vincent, 2008; Casquarelli \& Fallon, 2011).

There have been many studies conducted to improve the readiness of married life of the bride and groom including the research conducted, Najah et al., (2021) the prospective bride and groom development program contributed $70.04 \%$ to the readiness for marriage. Stanley (2001) conducted a study on premarital training as a prevention and relationship improvement program that can reduce the risk of dissolution of marriage. Friedman \& Lipchik (1999) explained the results of their research that premarital counseling can increase marriage readiness. Wright (1992) explains his research that, premarital counseling can bridge the expectations of the couple and the expected marriage. Stanley et al., (2001) found the results of their research that communication skills in premarital guidance are the most helpful things in marriage.

Subsequent research by Murray \& Murray (2004) found that solution-focused premarital counseling is a strengths-based approach that focuses on partner resources to develop a shared vision for marriage. Almost simultaneously with Irman \& Elvira (2015), the results of their research found that there was an effect of solution focused premarital counseling on increasing the concept of the prospective bride's sakinah family. Wright \& Wright (1992) research found that, premarital counseling can help develop empathy, learn to compromise, and communicate successfully, and can maintain desire in long-term relationships. Schilling (2010) research found that, premarital counseling can prevent the development of marital stress and divorce. Sakdiyah (2021) found that premarital counseling based on the integration of psychology \& Islam can build a strong marriage towards a sakinah family.

Various studies have been carried out related to premarital counseling, but specifically no one has conducted research to specifically accommodate the values held by clients. This study tries to 
accommodate client values in Tanah Datar, as the object of research, namely spiritual values. Irman et al., (2020) stated that counseling can be used as a very effective approach in building spiritual values. spiritual-based counseling is Islamic premarital counseling. Musnamar (1992) explains that premarital counseling in Islam is the process of providing assistance to the bride and groom so that in carrying out their marriage and married life in harmony with Allah's provisions and instructions so that they can achieve happiness in the world and in the hereafter.

The application of Islamic premarital counseling aims to build readiness for married life of the bride and groom. Through premarital counseling, it is hoped that the bride and groom will understand the role of husband and wife in managing life to foster a household (Triningtyas \& Muhayati, 2017). The family will run as it should if they carry out their respective roles, so that they will get the happiness of married life (Mubasyaroh, 2017). This means that through Islamic premarital counseling, it is hoped that the bride and groom will have the readiness to live in a household by understanding their respective roles to get a happy family according to Allah's instructions. The application of Islamic premarital counseling is also expected to reduce the divorce rate. To test the effectiveness of Islamic premarital counseling on increasing the readiness for married life of the prospective bride, it was carried out in the form of an experiment.

\section{METHOD}

This research is intended to see the effectiveness of Islamic premarital counseling to increase the readiness of married life of the prospective bride and groom in the office of religious affairs (KUA) Tanah Datar. The researcher used this type of experimental research, with one group pretest and posttest design.

The variables contained in this study include; the independent variable is Islamic premarital counseling which is the variable that is observed and is estimated to affect the dependent variable. While the dependent variable is the readiness of married life of the bride and groom, which consists of several dimensions, namely; (1) mental dimension, (2) financial dimension, (3) social dimension, and (4) spiritual dimension.

The population of this research is the bride and groom who are in KUA Tanah Datar Regency. The process of determining the sample is based on consideration of the level of readiness to enter the married life of the bride and groom who are in the very low and medium range categories. The population selection process is carried out using a 
readiness scale instrument to enter married life, which is compiled based on indicators of readiness to enter married life. The form of determining the research sample is based on purposive sampling which will be carried out on the prospective bride and groom who will get married. The number of samples in this study were 8 prospective brides who were going to get married at the religious affairs office.

The validity of the research in this study uses internal validity and external validity. Internal validity refers to the ability of a research design to dispel doubts or create plausible alternative explanations of research results (Kazdin, 2003). The external validity refers to the extent to which the generalization of research results related to conditions, samples, time, and place (Graziano \& Raulin, 2004).

The instrument in this study uses a scale of readiness of the bride and groom to enter married life. The instrument used has passed the instrument validity test by (a) consulting the instrument with colleagues and (b) testing the instrument to the bride and groom. While the reliability test is to see the internal consistency of a test or scale (Kerlinger, 2006). The instrument reliability test that has been carried out with reliability analysis is obtained by Cronbach's Alpha value of 0.793. Furthermore, statistical analy sis was carried out on the married life readiness score of the bride and groom based on the comparison of pretest and posttest scores. Hypothesis testing using paired $\mathrm{t}$ test, through parametric statistics with SPPS for Windows version 20.0.

\section{RESULT AND DISCUSSION}

The bride and groom who will get married are couples who have a high commitment to build a life together. Commitment in building a household must be accompanied by readiness to build a married life, including mental, financial, social and spiritual readiness. The pretest and posttest data on the level of readiness for married life of the bride and groom are as shown in the following table.

Based on Table 1 above, it can be explained that the pretest and posttest data on the level of readiness for married life of the bride and groom as many as 8 respondents, obtained a total pretest score of 596 points with an average value of 74.5 points in the low category. While the total posttest score was 871 points with an average of 108.88 points in the medium category. This means that there has been an increase in the total score of married life readiness of the bride and groom after receiving Islamic premarital counseling by 275 points with an average increase of 34.38 points. Through Islamic premarital counseling there has been a change in the 
readiness of the married life of the bride and groom from low readiness to medium.

In more detail, to see changes in the married life readiness score of the bride and groom based on the dimensions of married life readiness, the data is as follows.

Figure 1. Pretest and Posttest Data Dimensions of Marriage Readiness for Prospective Bride and Groom

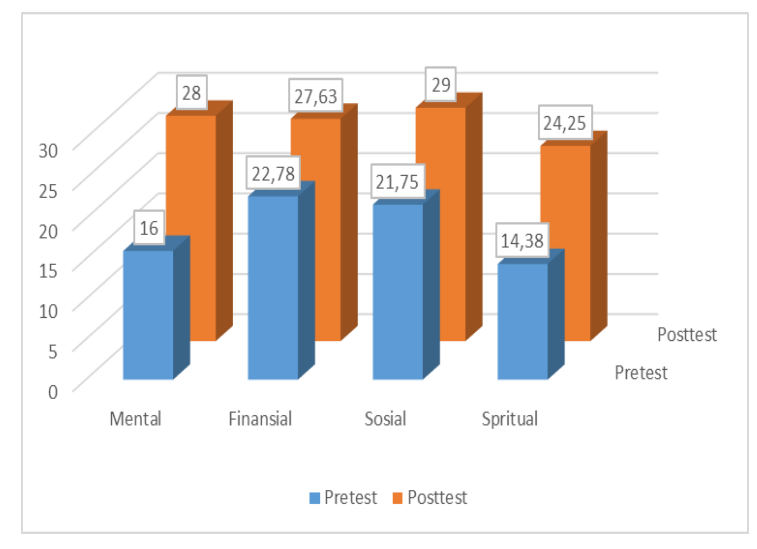

Based on Figure 1 above, it can be explained that the comparison of pretest and posttest data on married life readiness of the bride and groom in four dimensions, namely; the mental dimension obtained an average pretest score of 16 points in the low category. After receiving the intervention, the posttest average score of 28 points was in the high category. When compared to the average value of the pretest with the posttest, there was an increase of 12 points, and there was a change in the mental readiness of the prospective bride and groom from low to high category.
As for the readiness for married life of the prospective bride and groom on the financial dimension, the average pretest score of 22.78 points is in the medium category and the posttest average value of 27.63 points is in the high category. Comparison of the average value of the pretest with the posttest there was an increase of 4.85 points, and there was a change in the financial readiness of the bride and groom from the medium category to the high category.

In the social dimension, the average pretest score of 21.75 points is in the medium category and the posttest score of 29 points is in the high category. This shows an increase in the average score of 7.25 points, and there is a change in the social readiness of the replacement candidate from the medium category to the high category. As for the spiritual dimension, the average pretest score of 14.38 points is in the very low category and the posttest average value of 24.25 points is in the high category. When compared to the average value of spiritual readiness, there was an increase of 9.87 points and there was a change in spiritual readiness from the very low category to the high category. This means that overall there has been an increase in each dimension of readiness for married life and there has been an increase. In detail the changes that occur there are differences in 
improvement, the mental and spiritual dimensions of readiness for married life are the highest dimensions compared to other dimensions.

Next is hypothesis testing, to determine the statistics used, the data first goes through a prerequisite test. Prerequisite tests carried out are normality and homogeneity tests. The normality test is carried out to test whether the distribution of data on the level of readiness for married life of the prospective bride and groom comes from a sample that is normally distributed or not.

Testing the normality of the data distribution was carried out using the parametric test method, namely the OneSample Kolmogorov-Smirnov Test table. The rule used to determine whether the data distribution is normal or not is if $p>$ 0.05 , then the distribution is normal, and vice versa if $p<0.05$ then the distribution is considered abnormal. The results of the normality test are as contained in the following table.

Based on Table 4.11 above, it shows that the statistical value of the Kolmogorov-Smirnov test, the pretest score of the married life readiness level of the bride and groom, obtained $\mathrm{p}$ value = 0.199 and posttest data with $\mathrm{p}$ value $=$ 0.073 . It can be interpreted that the data follow a normal distribution ( $\mathrm{p}>0.05)$. So that the pretest and posttest data have met the assumptions that are the requirements for using the planned statistical method.

The next test is the homogeneity test. The homogeneity test aims to find out whether the pretest and posttest data have the same variance or not. In other words, homogeneity means that the data set we are studying has the same characteristics. This homogeneity is determined based on the value of Levene's test of homogeneity variance. The stipulation is that the variation in the level of readiness for married life of the bride and groom in each condition is declared homogeneous if the Levene's test of homogeneity variance produces an insignificant $\mathrm{p}$ value $(\mathrm{p}>$ 0.05). Based on calculations with SPSS, the results are as shown in table 4.9 below.

Based on Table 3 above, it can be shown that the results of the homogeneity test of the pretest data variance are $\mathrm{p}=$ 0.168 and the posttest is $p=0.072$. It can be interpreted that the results of the pretest and posttest data on the level of readiness for married life of the prospective bride and groom are homogeneous $(\mathrm{p}>0.05)$. So that the pretest and posttest data meet the assumptions that are the requirements for using the planned statistical method.

Furthermore, hypothesis testing was carried out on the pretest and posttest scores of the married life readiness level of the bride and groom. Testing of the hypothesis is carried out through a paired $t$ 
test, with the basic assumption for making decisions using a 95\% confidence level (p $=0.05)$, because in social science standards the error that can be tolerated is $5 \%$ of $100 \%$. Rejection and acceptance of each hypothesis is based on the magnitude of the p-value or significant level (sig) of the results of the analysis, compared to the alpha value of $5 \%(0.05)$. If the $p$-value is greater than 0.05 then the null hypothesis (Ho) is accepted, and if the p-value is less than 0.05 then the null hypothesis is rejected. The acceptance and rejection of the null hypothesis means the opposite of the acceptance and rejection of the research hypothesis. In the following, an explanation of the results of the paired $t$ test will be presented, as shown in the following table.

In Table 4 above, it can be seen that the average pretest score for the marriage readiness level of the bride and groom is 74.5 points and the average posttest score is 108.88 points. This means that there is a difference in the level of readiness for household life between the pretest and posttest as many as 34.38 points. The results of the paired test obtained $\mathrm{p}$ value $=0.009$. It turns out that the $\mathrm{p}$ value $<0.05$, this provides evidence that there is a significant difference in the level of readiness for married life of the bride and groom after receiving Islamic premarital counseling intervention. This empirical evidence supports the hypothesis in this study, namely Ho is rejected and $\mathrm{Ha}$ is accepted. This means that Islamic premarital counseling is effective to improve the readiness of married life of the bride and groom.

Various efforts have been made to improve the readiness for married life of prospective brides, so that divorce does not occur, one of which is through Islamic premarital counseling. Based on data analysis, after the intervention, it was found that Islamic premarital counseling was effective in increasing the readiness for married life of the bride and groom. Increased readiness for married life of the bride and groom also occurs in the mental, financial, social and spiritual dimensions.

The four dimensions have a higher increase in the mental and spiritual dimensions. This means that Islamic premarital counseling is very effective in increasing the readiness for married life in the mental and spiritual dimensions. In the premarital counseling process, the prospective bride and groom always have problems in these two dimensions, but after the bride and groom undergo the Islamic premarital counseling process, they are able to build mental and spiritual strength.

The process of living a married life, mental and spiritual readiness is an important part of maintaining the integrity 
of married life, meaning that through these two strengths it is predicted that the bride and groom will be able to build a sakinah family and avoid divorce. This does not deny the importance of the financial and social dimensions in domestic life, but these dimensions continue to increase in Islamic premarital counseling, but the increase is not as high as the increase in the mental and spiritual dimen sions. If the ranking is carried out to increase the readiness for married life through Islamic premarital counseling, it can be sorted as follows; The first is the mental dimension, the second is the spiritual dimension, the third is the social dimension, and the fourth is the financial dimension.

The four dimensions of readiness to live at home are an important part of building readiness to live at home. This finding is in line with the research of Muluhya et al., (2020) which states that there is a statistically significant relationship between premarital counseling services and marital harmony. This means that through premarital counseling the couple will be able to get a sakinah family.

Given the importance of increasing married life readiness through premarital counseling, premarital counseling is an important part that must be implemented. Currently premarital counseling is getting a lot of attention around the world because the government requires premarital counseling as a means to reduce divorce (Stahmann, 2000). Even some states of America have marriage laws that require premarital counseling for prospective brides (Alphonso, 2016). Whereas in the United States the problem of divorce has disrupted the lives of children, families and the general public, so the government mandates premarital counseling for all couples planning marriage (Licata, 2005). This means that premarital counseling is a very important part of maintaining the social stability of a country. In more detail, the causes of divorce that occur in this country are caused by adolescent attitudes towards marriage and expectations in marriage reflect many that are unrealistic (Silliman \& Schumm, 2004). This means that changing the perspective of marriage is an important part of teenagers who will enter married life.

Research in America emphasizes changing perspectives through premarital counseling. If it is associated with the results of research on Islamic premarital counseling, it is much more effective in changing the improvement of married life readiness through mental, spiritual, social and financial improvement of the prospective bride and groom. The results of this study are also in line with the research of Wright \& Roberts, (2019) that premarital counseling can help explore relationships in depth, provide new 
insights about couples, how to relate to each other, put openness and honesty, create stronger and healthier marriages, decision-making in marriage, and help plan for a lasting future.

The need for premarital counseling is not only for the bride and groom, but also better given to teenagers in college. Meadows \& Taplin (1973) research results recommend premarital counseling as a service that is appropriate and needed in a college environment. The need for premarital counseling is so high and important that the government is expected to include it in the law as a prerequisite for marriage. The application of premarital counseling for prospective brides is a form of government concern for the validity of marriages (Karim, 2020).

The application of premarital counseling in question must be in line with the conditions of local wisdom. Specificall for Batusangkar and West Sumatra, in general, the most appropriate pre-marital counseling is Islamic pre-marital counseling in accordance with the results of research that has been carried out. Through Islamic premarital counseling, counselors can apply various techniques according to the cultural conditions adopted by the client. Through this research, it can also be followed up by the local government of Tanah Datar in particular and the province of West
Sumatra in general to require the bride and groom to attend Islamic premarital counseling as a condition of marriage. This policy is an important part of reducing the divorce rate which is quite high in Tanah Datar in particular and Indonesia in general.

\section{CONCLUSION}

Based on the results of data analysis, it turns out that Islamic premarital counseling is effective in increasing the readiness for married life of the bride and groom. The increase also occurred in every dimension of married life readiness, namely mental, spiritual, social and financial readiness, while the highest increase occurred in the mental and spiritual dimensions. Through this research, it is suggested to the local government in West Sumatra to produce a policy, requiring the bride and groom to follow Islamic premarital counseling as a condition of marriage.

\section{REFERENCES}

Al-Qur'an

Alphonso, C. (2016). Covenant Marriage. In C. L. Shehan (Ed.), Encyclopedia of Family Studies (pp. 1-5). John Wiley \& Sons, Inc. https://doi.org/10.1002/9781119085 621.wbefs 080

Alpaslan, N. (1997). Methods And Means For A Meaningful Marriage. Pretoria: Kagiso Publishers. 
BPS Tanah Datar. (2021). Badan Pusat Statistik Tanah Datar.

Carroll, J.S \& Doherty, W.J. (2003). Evaluating the Effectiveness of Premarital Prevention Programs: A Meta-analytic Review of Outcome Research. Family Relations, 52, 105-118.

Conger, J.J. (1993). Perkembangan dan Kepribadian Anak. Jakarta: Gramedia Pustaka.

Casquarelli, E. J., \& Fallon, K. M. (2011). Nurturing the Relationships of All Couples: Integrating Lesbian, Gay, and Bisexual Concerns into Premarital Education and Counseling Programs. The Journal of Humanistic Counseling, 50(2), 149-160.

https://doi.org/10.1002/j.2161-

1939.2011.tb00114.x

Chadijah, S. (2018). Karakteristik

Keluarga Sakinah Dalam Islam.

Rausyan Fikr : Jurnal Pemikiran

Dan Pencerahan, 14(1).

https://d oi.org/10.31000/rf.v14i1.67

6

Djam'an. N. (1993). Fiqh Munakahat.

Semarang: Dina Utama Press.

Friedman, S., \& Lipchik, E. (1999). A Time-effective, Solution-focused Approach to Couple Therapy. In Donovan, J. M, (Ed.), Short-term Couple Therapy (pp, 325-359). New York: Guilford Press.

Giblin, P., Sprenkle, D.H., \& Sheehan R. (1985) Enrichment Outcome Research: A Meta-analysis of Premarital, Marital, and Family Interventions. Journal of Marital and Family Therapy, 11(3) 257-271

Graziano, A.M \& M.L Raulin. (2004). Research Methods, A Process of
Inquiry, 8th ed. Boston: Allyn \& Bacin

Harian Singgalang. (2021).

https://www.topsatu.com/angka-

perceraian-di-tanah-datar-lima-

besar-di-sumbar/

Hoopes, M.H \& Fisher, B.L. (1984). A premarital education program. In MI. H. Hoopes, B. L. Fisher, \& S. H. Barlow (Eds.), Structured family facilitation programs (pp. 195-206). Rockville, MD: Aspen Systems.

Hurlock, E. (1980). Psikologi

Perkembangan: Akhir Masa

AnakAnak. (5th ed) Jakarta:

Erlangga

Idayu, H. (2018). Konseling Pranikah Dalam Upaya Meningkatkan Kesiapan Mental Menuju Keluarga Sakinah Pada Mahasiswi Psikologi Semester VIII Tahun Ajaran 2017/20118 UIN Sunan Ampel Surabaya (Skripsi). Surabaya: UIN Sunan Ampel.

Irman, I., Murisal, M., Syafwar, F., Silvianetri, S., Zubaidah, Z., \& Yeni, P. (2020). Membangun Kesadaran Spritual melalui Konseling Berbasis Surau dalam Pengembangan Pariwisata. Islamic Counseling: Jurnal Bimbingan Konseling Islam, 4(1), 51. https://doi.org/10.29240/jbk.v4i1.14 21

Irman, I., Saari, C. Z., Silvianetri, S., Rajab, K., \& Zalnur, M. (2019). The Effect of Zikir Relaxation in Counseling to Reduce Internet Addiction. Al-Ta Lim Journal, 26(1), 1-11. https://doi.org/10.15548/jt.v26i1.54 7

Irman, I., \& Elvira, N. (2015). Pengaruh Konseling Pranikah Solution 
Focused Terhadap Peningkatan Konsep Keluarga Sakinah Calon Pengantin. Proceding IAIN Batusangkar. 1(1), 135-157.

https://ojs.iainbatusangkar.ac.id/ojs/i ndex.php/proceedings/article/view/6 85

Kazdin, A. E. (2003) Reseaarch Design In Clinical Psychology. Boston: Allyn and Bascon

Kenedi, G. (2005). Model Konseling Pranikah Berorientasi Pengembangan Konsep Diri (Disertasi). Bandung: Universitas Pendidikan Indonesia.

Kerlinger. (2006). Asas-Asas Penelitian Behaviour. Edisi 3, Cetakan 7. Yogyakarta: Gadjah Mada University Press.

Krivickas, K.M, Sanchez, L.A, Kenney, C.T, Wright, J.D. (2010) .Fiery wives and icy husbands: Pre-marital counseling and covenant marriage as buffers against effects of childhood abuse on gendered marital communication?. Social Science Research, 39. 700-714.

Karim, H. A. (2020). Manajemen Pengelolaan Bimbingan Pranikah Dalam Mewujudkan Keluarga Sakinah Mawaddah Wa Rahmah. Jurnal Bimbingan Penyuluhan Islam, $\quad 1(2), \quad 321$. https://d oi.org/10.32332/jbpi.v1i2.1 721

Latipun. (2010). Psikologi Konseling. Malang: Universitas Muhammadiyah Malang Press.

Licata, N. (2005). Should Premarital Counseling Be Mandatory As A Requisite To Obtaining A Marriage License? Family Court Review, 40(4),

518-532. https://doi.org/10.1111/j.174-

1617.2002.tb00860.x

Lokadata. (2021). Perceraian di Indonesia terus meningkat. https://lokadata.id/artikel/perceraian -di-indonesia-terus-meningkat

Meadows, M. E., \& Taplin, J. F. (1973). Premarital Counseling with College Students: A Promising Triad. In Counseling and Accountability (pp. 101-109). Elsevier.

https://doi.org/10.1016/B978-0-08-

017029-9.50014-5

Mubasyaroh, M. (2017). Konseling Pra Nikah Dalam Mewujudkan Keluarga Bahagia (Studi Pendekatan Humanistik Carl R. Rogers). KONSELING RELIGI Jurnal Bimbingan Konseling Islam, 7(2), 1. https://d oi.org/10.21043/kr.v7i2.212 8

Muluhya Keverenge, E., Kipnusu, R. C., Tarus, P., \& Karimi, J. (2020). The relationship between premarital counselling and marital harmony among families in Lugari, Kakamega County, Kenya. Counselling and Psychotherapy Research, 20(3), 556-561. https://doi.org/10.1002/capr.12319

Murray, C. E., \& Murray, T. L. (2004). Solution-Focused Premarital Counseling: Helping Couples Build A Vision For Their Marriage. Journal of Marital and Family Therapy, 30(3), 349-358. https://doi.org/10.1111/j.17520606.2004.tb01245.x

Musnamar, T. (1992). Dasar-dasar Konseptual Bimbingan dan Konseling Islami. Yokyakarta: UII Prees.

Najah, U., Desyanty, E. S., \& Widianto, E. (2021). Kontribusi Program 
Pembinaan Calon Pengantin Terhadap Kesiapan Berumah Tangga Bagi Masyarakat Kota Malang. Aksara: Jurnal Ilmu Pendidikan Nonformal, 7(3), 1303. https://doi.org/10.37905/aksara.7.3.1 303-1312.2021

Nelson, T.S \& Kelley, L. (2001). Solutionfocused couple group. Journal of Systemic Therapies, 20, 47-66.

Rahmah, P.Y. (2018). Kesiapan Membangun Rumah Tangga (Studi Kasus Remaja Putri K-Popers Kota Malang). Malang: Universitas Islam Negeri Maulana Malik Ibrahim.

Rais, I. (2014). Tingginya Angka Cerai Gugat (Khulu') di Indonesia: Analisis Kritis terhadap Penyebab dan Alternatif Solusi Mengatasinya. Jurnal Al' Adalah.12(1),191-204. https://doi.org/10.24042/adalah.v12 il.183

Sakdiyah., Halimatus, E., \& Muallifah, M. (2021). Best practice konseling pra-nikah berbasis integrasi Psikologi \& Islam menuju keluarga sakinah, mawaddah, warahmah. UIN Maliki Press.

Schilling, E. A. (2010). Premarital Counseling. In I. B. Weiner \& W. E. Craighead (Eds.), The Corsini Encyclopedia of Psychology (p. corpsy0701). John Wiley \& Sons, Inc.

https://d oi.org/10.1002/9780470479 216.corpsy0701

Scott, H.V. (2012). Reducing the Divorce Rate Among Cristians in America Premarital Counseling A Prerequisite for Marriage. University Baptist Theological, Press. USA.

Silliman, B., \& Schumm, W. R. (2004). Adolescents' perceptions of marriage and premarital couple education. Family Relations, 53(5), 513-520.

https://doi.org/10.1111/j.01976664.2004.00060.x

Stahmann, R. F. (2000). Premarital counselling: A focus for family therapy. Journal of Family Therapy, 22(1), 104-116. https://doi.org/10.1111/14676427.00140

Stanley, S. M. (2001). Making A Case for Premarital Education*. Family Relations, 50(3), 272-280. https://d oi.org/10.1111/j.17413729.2001.00272.x

Stanley, S. M., Markman, H. J., Prado, L. M., Olmos-Gallo, P. A., Tonelli, L., St. Peters, M., Leber, B. D., Bobulinski, M., Cordova, A., \& Whitton, S. W. (2001). CommunityBased Premarital Prevention: Clergy and Lay Leaders on the Front Lines*. Family Relations, 50(1), 6776.

Sullivan, K. T., Pasch, L. A., Cornelius, T., \& Cirigliano, E. (2004). Predicting Participation in Premarital Prevention Programs: The Health Belief Model and Social Norms. Family Process, 43(2), 175-193. https://doi.org/10.1111/j.15455300.2004.04302004.x

Shihab, Q.M. (2006). Menabur Pesan Ilahi. Jakarta: Lentera Hati.

Stahmann, R.F \& Hiebert, W.J. (1980). Premarital counseling. Lexington, MA: Lexington Books.

Stanley, S.M. (2000). Making a case for premarital education. an paper presented at the Revitalizing Marriage Conference at Brigham Young University. Brigham: Family Studies Center. 
Triningtyas, D. A., \& Muhayati, S. (2017).

Konseling Pranikah: Sebuah Upaya

Meredukasi Budaya Pernikahan

Dini di Kecamatan Pulung

Kabupaten Ponorogo. JKI (Jurnal

Konseling Indonesia), 3(1), 28-32.

https://d oi.org/10.21067/jki.v3i1.19

76

Undang-Undang No.1 Tahun 1974

Tentang Perkawinan.

Vincent, B. (2008). Toward a Premarital

Counselling Model. The School of

Relegion ang Theology Faculty of

Humanities, Development and social Sciences, The University of Kwazulu-Natal Press.

Willis, S.S. (2008). Konseling Keluarga. Bandung: Penerbit Alfabeta.

Wright, H. N., \& Wright, H. N. (1992).

The premarital counseling handbook. Moody Press.

Wright, H. N. (2003). Before You Say "I Do" Devotional. Oregon: Harvest House Publisher.

Wright, H. N., \& Roberts, W. (2019).

Before you say "I do." Harvest

House Publishers.

http://search.ebscohost.com/login.as

px?direct $=$ true $\&$ scope $=$ site $\& \mathrm{db}=$ nle

bk\&db=nlabk\&AN=2032104

Zulkifli. (1987). Psikologi Perkembangan.

Bandung: Remaja Rosada Karya. 
Table. 1 Pretest and Posttest Data on Marriage Readiness of Prospective Bride and Groom

\begin{tabular}{|c|c|c|c|c|c|c|}
\hline \multirow[t]{2}{*}{ No } & \multirow[t]{2}{*}{ Responden } & \multicolumn{2}{|c|}{ Data Pretest } & \multicolumn{2}{|c|}{ Data Posttest } & \multirow[t]{2}{*}{ Deviation } \\
\hline & & Score & Catogory & Score & Category & \\
\hline 1 & AA & 69 & Low & 112 & High & 43 poin \\
\hline 2 & $\mathrm{BB}$ & 88 & Medium & 115 & High & 27poin \\
\hline 3 & $\mathrm{CA}$ & 72 & Low & 110 & High & 38 poin \\
\hline 4 & DB & 75 & Low & 105 & Medium & 30 poin \\
\hline 5 & EA & 96 & Medium & 120 & High & 24 poin \\
\hline 6 & FB & 64 & Low & 99 & Medium & 35 poin \\
\hline 7 & GA & 75 & Low & 107 & Medium & 32 poin \\
\hline 8 & $\mathrm{HB}$ & 57 & Very Low & 103 & Medium & 46 poin \\
\hline & Total & 596 & & 871 & & 275 \\
\hline & Median & 74,5 & Low & 108,88 & Medium & 34,38 \\
\hline
\end{tabular}

Table 2. Normality Test Results of Pretest and Posttest Data Distribution

\begin{tabular}{cccccc}
\hline No & Data & N & $\boldsymbol{K}-\boldsymbol{Z}$ & $\boldsymbol{P}$ & Result \\
\hline $\mathbf{1}$ & Pretest & 8 & 0,292 & 0,199 & Normal distribution \\
\hline $\mathbf{2}$ & Posstest & 8 & 0,409 & 0,073 & Normal distribution \\
\hline
\end{tabular}

Table 3. Results of Homogeneity Test of Pretest and Posttest Data Distribution

\begin{tabular}{ccc}
\hline Data & F & $\boldsymbol{P}$ \\
\hline Pretest & 1,240 & 0,168 \\
\hline Posttest & 2,496 & 0,072 \\
\hline
\end{tabular}

Table 4. Results of Paired T Test

\begin{tabular}{|c|c|c|c|c|}
\hline Data & $\mathbf{N}$ & Mean Score & Deviation & $\mathbf{p}$ \\
\hline Pretest & 8 & 74,5 & 34,38 & 0,009 \\
\hline Posttest & 8 & 108,88 & & \\
\hline
\end{tabular}

